International Journal on Social Science, Economics and Art, 11 (1) (2021) 1-11

\title{
Indonesia's Efforts in Resolving South China Sea Conflict
}

\author{
Wines Aprilla \\ Department of Political Science, Faculty of Social and Political Sciences, Universitas Sumatera Utara, Indonesia
}

\begin{tabular}{|c|c|}
\hline Article Info & ABSTRACT \\
\hline Article history: & This research tries to explain Indonesia's effort in the South \\
\hline & China Sea conflict resolution process. The South China Sea \\
\hline Received: Jan 9, 2020 & conflict can lead to regional instability. Indonesia can't directly \\
\hline Revised: Nov 20, 2020 & resolve the conflict because Indonesia is not a claimaint state. \\
\hline Accepted: Apr 11, 2021 & $\begin{array}{l}\text { But, Indonesia can encourage claimant states to resolve their } \\
\text { conflicts peacefully. As the largest country in ASEAN, Indonesia }\end{array}$ \\
\hline Keywords: & $\begin{array}{l}\text { has an obligation to maintain the stability of the region. The } \\
\text { type of this research is descriptive qualitative with data } \\
\text { collection technique through interview and literature study. }\end{array}$ \\
\hline Conflict; & The results concluded that Indonesia's efforts in establishing \\
\hline South China Sea; & the situation through confidence buiding measures and \\
\hline National Interest; & cooperation has been able to dampen the source of conflict and \\
\hline Regional Stability. & $\begin{array}{l}\text { keep the region stable. Indonesia has managed conflict even } \\
\text { though it is still very far from the possibility of conflict } \\
\text { resolution. }\end{array}$ \\
\hline
\end{tabular}

This is an open access article under the CC BY-NC license.

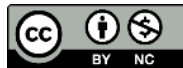

\section{Corresponding Author:}

Aprilla Wines,

Department of Political Science, Faculty of Social and Political Sciences,

Universitas Sumatera Utara,

Street Dr. T. Mansur No. 9, Padang Bulan, Medan, 20155, North Sumatra, Indonesia

Email: wines@gmail.com

\section{INTRODUCTION}

International relations between countries have not always worked out well. The attitude of countries that will always pursue their national interests, causes conflicts of interest between countries in the world. These interests can create good cooperative relations between countries and can also lead to conflicts. If cooperation is not established, what will happen is conflict. Conflict can threaten existing diplomatic relations, even the worst impact is triggering war between countries.

Conflicts between countries can occur, among others, due to problems with borders, natural resources, environmental damage, trade, and others. The South China Sea conflict is one of the conflicts in the East Asian region that arises because of the state's interest in the region's abundant natural resources. Over the centuries a number of countries have fought over this territory and have resulted in unresolved disputes. Until now, there has been no common ground between the countries involved in resolving the conflict.

Geographically, the South China Sea stretches from the southwest to the northeast, whose southern boundary is $3^{-0}$ South latitude between Sumatra and Kalimantan (Karimata Strait), and the 
northern boundary is the Taiwan Strait, from the northern tip of Taiwan to the Fujian coast in mainland China. South China is a semi-closed sea with a sector area of 3,500,00o km. The South China Sea borders China, Macao, Hong Kong, Taiwan, the Philippines, Malaysia, Brunei, Indonesia, Singapore, Thailand, Cambodia and Vietnam. In these territorial waters, several archipelagic groups are scattered, namely: (1) the Pratas Islands group; (2) the Paracel Islands group; and (3) the Spratly Islands group. In addition there is also the Macclesfield Bank coral cluster.

The potential of natural resources in the South China Sea is the biggest factor in the emergence of conflict. This sea is known to contain abundant oil and natural gas and even contains a lot of fish which can be a source of nutrition for the Asian population. Apart from that, the strategic position of the South China Sea is another factor why this region is being contested. More than half of the world's oil transports pass through the South China Sea from the Middle East to China, Japan, Taiwan and South Korea each year. The South China Sea can be a source of life for the surrounding countries(Kaplan, 2011)(Yahuda, 2013)(Hayton, 2014). This region contributes a lot in terms of meeting the needs of countries which will also have an impact on the country's economy(Sussangkarn, 2011). This is a fundamental reason for countries that have interests in the South China Sea(Storey, 2013).

The South China Sea dispute has existed since the 19th century, when Britain occupied and claimed the Spartly Islands(Gao \& Jia, 2013). Then in the zoth century China also claimed the area and was followed by France around the 1930s. When World War II took place, this area was successfully captured by Japan from France until when the war ended, China and France reclaimed the area. The Philippines, which needs part of the South China Sea for its national security interests, also claimed. Since 1970, claims to the South China Sea area have begun to increase. The nature of disputes in the South China Sea is basically caused by two things, namely: (1) the Law of the Sea or the United Nations Convention On the Law of the Sea (UNCLOS) which came into force in 1982 and was ratified by several countries around these waters. Referring to existing regulations regarding internal waters, archipelagic waters, territorial waters, additional zones, exclusive economic zones, continental shelves and high seas, the surrounding countries seek to expand their territories. In other words, the countries concerned have abused the existing laws of the sea(Beckman, 2013). (2) Overlapping claims. In general, the six countries, namely China, the Philippines, Vietnam, Taiwan, Malaysia and Brunei Darussalam, use historical and geographic bases in competing for property rights over the area. Their claims are not supported by any basis and there is no clear boundaries of the areas claimed. Apart from that, different interpretations of the Law of the Sea (UNCLOS 1982) also make states claim based on the extension of sovereign jurisdiction. China is the country that claims the most areas in the South China Sea. China's claim to the area is based on the Chinese ownership of the sea area and the Paracel and Spratly islands since 2000 years ago. In 1947, the Chinese Government issued a map depicting Chinese sovereignty over the South China Sea and known as the "nine dashed lines"(Pedrozo, 2011). The map contains nine dotted lines covering almost the entire area of the South China Sea. Chinese claims are submitted based on the principle of "historic waters" or waters which according to Chinese history are part of China's territory or jurisdiction. The Chinese government also calls the nine dashed lines their traditional fishing ground Such as China, the Philippines, Vietnam, Taiwan(Delisle, 2012).

Vietnam is the country with the second most claims after China. Vietnam claims the Paracel Islands cluster located southeast of Hainan along with its EEZ and continental shelf, as well as the entire Spartly archipelago. Unlike China and Vietnam, the Philippines only claims a group of Scarborough Shoal islands in the Spartly archipelago and its continental shelf(Chakraborti, 2012). Meanwhile, Malaysia only claims a small number of areas in the Spartly archipelago that are part of its EEZ. Then the countries that claim the least are Brunei Darussalam which claims the Louisa Reef, which is also claimed by Malaysia, and Rifleman Bank(Hong, 2012).

The South China Sea conflict has the potential to create regional instability(Dutton, 2011). The overlapping claims of territories in the South China Sea have caused tensions between the disputing parties, and even had a military conflict that resulted in casualties. In 1991, to formalize claims against the Spratly and Paracels, China issued the Law on the Territorial Sea and the Contiguous Zone of the 
Republic of China(Yahuda, 2013). Then four years later, the Philippine military installation at Mischief Reef, Spratly Islands was captured by China(Kaplan, 2011). In May 200o, it was the turn of the Philippines to take action by shooting dead one fisherman and arresting seven Chinese fishermen who were passing through Philippine waters near Palawan Island(Pham, 2016). In recent years, tensions over claims in the South China Sea have intensified. The countries involved in the dispute continue to work to defend their claims(Scott, 2012). Even these countries have strengthened their military capabilities, and some are also exploring legal avenues. China, for example, has built a sea base in Sanya that can serve as a gateway to the South China Sea.17 In 2013, China also increased its military budget to 150 billion dollars(Hu \& McDorman, 2013).

While overlapping claims have not been resolved, incidents have continued to emerge in the South China Sea region. China's military superiority that far surpasses that of other claimant countries has encouraged China to be more courageous in acting to defend its claims. Thus, the potential for armed conflict is much greater than in the 1990 (Pertiwi, n.d.)(Coker, 2015). The existence of Chinese actions that threaten freedom of navigation and smooth international trade routes will also invite more interested parties to get involved in the event of a conflict in the South China Sea(Chaturvedy, 2015). The position of the South China Sea, which is so prone to conflict, has huge implications for later armed conflict in these waters. The South China Sea conflict will affect regional stability, Moreover, four of the six countries involved in the conflict are ASEAN member countries. Until now, there is no institution or international organization that can resolve disputes. If this is not immediately addressed by finding an effective solution, the conflict will further develop and put the security and stability of the area under threat.

The Vision of the ASEAN Community 2025 in the points of the ASEAN Political Security Community wants a united, inclusive and resilient society by 2025. ASEAN remains cohesive, responsive and relevant in overcoming various challenges to regional peace and security and plays a major role in shaping the regional architecture which continues to develop, while deepening relations with external parties and contributing collectively to global peace, security and stability. In one of its points, ASEAN seeks to create a region that can resolve differences and disputes in a peaceful manner, including refraining from using threats or force, and implementing peaceful dispute resolution mechanisms while strengthening steps to build mutual trust, encourage preventive diplomacy and conflict resolution initiatives. The ASEAN vision is a good impetus for the resolution of the South China Sea conflict which is indeed a concern for ASEAN countries. Conflict resolution efforts have actually been a concern in the international community since the early zoth century. These efforts are made to create better relations between countries based on the principles of international peace and security. Achieving South China Sea conflict resolution is not only beneficial economically, but also politically and securely for every country involved. The impact of conflict resolution can be enjoyed not only by communities around the South China Sea but also for Indonesia and the international community. The ASEAN vision is a good impetus for the resolution of the South China Sea conflict which is indeed a concern for ASEAN countries(De Castro, 2012). Conflict resolution efforts have actually been a concern in the international community since the early zoth century. These efforts are made to create better relations between countries based on the principles of international peace and security. Achieving South China Sea conflict resolution is not only beneficial economically, but also politically and securely for every country involved. The impact of conflict resolution can be enjoyed not only by communities around the South China Sea but also for Indonesia and the international community. The ASEAN vision is a good impetus for the resolution of the South China Sea conflict which is indeed a concern for ASEAN countries. Conflict resolution efforts have actually been a concern in the international community since the early 2oth century(De Castro, 2012). These efforts are made to create better relations between countries based on the principles of international peace and security. Achieving South China Sea conflict resolution is not only beneficial economically, but also politically and securely for every country involved. The impact of conflict resolution can be enjoyed not only by communities around the South China Sea but also for Indonesia and the international community. Conflict resolution efforts have actually been a concern in the international 
community since the early 2oth century. These efforts are made to create better relations between countries based on the principles of international peace and security(De Castro, 2012).

However, in the context of the South China Sea conflict, conflict resolution is quite difficult to achieve. It is difficult because there are more than five countries involved in the conflict. The main solution to the South China Sea conflict is when there is strong evidence of states claiming authority over islands or territorial boundaries. However, what is needed by the countries involved is how to keep regional conditions stable, while waiting for a common ground from countries to resolve conflicts. These various efforts have actually been made by the countries involved, for example, such as the agreement made between China and the Philippines (1995) and the Philippines and Vietnam (1996) in the formation of Confidence Building Measures, a code of ethics between them. However, the agreement turned out to be not strong enough to form confidence building measures or trust between them. In fact, China is again carrying out the construction of artificial islands in the South China Sea. Recently, the Philippines has chosen to settle disputes through the Permanent Court Abritration (International Arbitration Court). In 2013, the Philippines filed a main case regarding the nine dashed lines claim made by China regarding the Scarborough Shoal area and a coral island. The Philippines says China's claims to these areas are baseless as they conflict with the Law of the Sea (UNCLOS 1982)(Song, 2015). In this case, neither historical records nor historical records can be considered as a legal basis for zoning. In July 2016.

China is even considered to have violated the sovereign rights of the Philippines and emphasized that China has caused environmental damage in the South China Sea by building artificial islands. China's rejection of the Court of Arbitration's decision suggests that the conflict in the South China Sea will enter a new, increasingly heated chapter. China seems to show that it will continue to insist on its territorial claims and completely ignore the existing and mutually agreed upon International Law of the Sea (UNCLOS 1982). This also seems to indicate that conflict resolution by legal methods has not been achieved. Since its proclamation, Indonesia through its free and active foreign policy has continuously made a positive contribution to the resolution of international conflicts. In the South China Sea conflict, Indonesia has also attempted to resolve disputes in the region. The thing that underlies Indonesia's attitude in the conflict is its position as an ASEAN member country that wants safe and stable conditions in the region. As the largest country among ASEAN countries, Indonesia certainly has a responsibility to maintain regional stability. This is what encourages Indonesia to continue working on things that can help the process of resolving the conflict. Apart from that, economically, Indonesia's interests must also be disturbed by the conflict. Considering the number of trade between Indonesia and countries in East Asia is quite high. The oil and gas production process in Natuna will also be disrupted and of course disturb the state's income. This is even more so if it is related to China's nine dashed lines claim regarding Indonesia's EEZ in the north of the Natuna Islands(Rustandi, 2016). If China flatly rejects the results of the 2016 Arbitration Court ruling on the Philippines' lawsuit, it is possible that China will continue to persist in defending its claim. Thus, Indonesia should be more active in conducting diplomacy to countries that are directly involved in the conflict. Indonesia must continue to strive so that claimant states resolve conflicts in a peaceful way and do not do things that trigger war. it is possible that China will continue to insist on defending its claim. Thus, Indonesia should be more active in conducting diplomacy to countries that are directly involved in the conflict. Indonesia must continue to strive so that claimant states resolve conflicts in a peaceful way and do not do things that trigger war. it is possible that China will continue to insist on defending its claim. Thus, Indonesia should be more active in conducting diplomacy to countries that are directly involved in the conflict. Indonesia must continue to strive so that claimant states resolve conflicts in a peaceful way and do not do things that trigger war.

\section{RESEARCH METHOD}

According to Cassel and Simon, the qualitative method is a social science research method that seeks to make an accurate description and interpretation of the meaning of the symptoms that occur in a 
social context. In this case, we see what effects one thing has on other things so that this research approach focuses on how the data is collected during research. This research is a qualitative research, where the researcher will look for any efforts made by Indonesia related to conflict resolution in the South China Sea. This type of research is descriptive research, namely research on certain phenomena or populations obtained by researchers from subjects in the form of individuals, organizational, industrial or other perspectives(Johnson, 2015). Descriptive research aims to answer questions about who, what, when, where and how are related to the characteristics of the population or phenomenon. The data used are primary and secondary data obtained from interviews with sources related to this research and studying books, print media, journals and several internet sites related to this research. After that data analysis is carried out, qualitative data analysis according to Bognan \& Biklen is an effort made by working with data, organizing data, sorting it into manageable units, synthesizing it, looking for and finding patterns, finding what is important and what is learned. and decide what to tell others. Based on the above definition, it can be concluded that the initial step of data analysis is to collect existing data, arrange it systematically, then present the research results. The data analysis technique used in this research is descriptive qualitative analysis. Qualitative data analysis provides research results to obtain an overview of the process under study and to analyze the meaning behind the data information and the process. Furthermore, conclusions will be drawn based on the problems that have been formulated. This qualitative data analysis is intended to answer research questions, namely the efforts made by Indonesia in resolving the South China Sea conflict.

\section{RESULTS AND DISCUSSIONS}

\subsection{The South China Sea Conflict and Its Impact on Indonesia}

As the largest country among countries in Southeast Asia, Indonesia has an obligation to maintain regional stability. The South China Sea conflict will certainly threaten regional peace and stability. This condition is against Indonesia's political interests. in participating in maintaining world peace and order including regional stability as mandated in the Preamble to the 1945 Constitution of the Republic of Indonesia(Acharya, 2014). In the 2007 Indonesian National Defense Doctrine, the achievement of defense targets in realizing world peace and regional stability is part of the national defense mission which all the time it has been fought for by Indonesia as part of the international community which is under global and regional influence(Laksmana, 2011). The realization of world peace and regional stability are national interests that must be fought for and enforced. The South China Sea conflict will also have significant political implications for Indonesia. On the one hand, the implication is that Indonesia will be caught in a battle between the interests of major powers in the region, namely the United States versus China. The United States with a new orientation of its security policy in Asia Pacific, wants to establish a more real, massive and intensive presence to counterbalance China's power. In addition, the United States will certainly always interfere in the South China Sea conflict in the name of the interests of freedom of navigation for its navy, especially in the deployment of power from the Asia Pacific region to the Indian Ocean region and vice versa.

Meanwhile, China is increasingly developing with its military strength. The large amount of defense budget and defense equipment owned by China cannot be defeated by other claiming countries even if they are combined. The South China Sea is a flash point in the Asia Pacific region, because it is one of the regions that has the potential for large oil and natural gas wealth in the world. In addition, several ASEAN countries disputing the South China Sea have defense alliances with major powers. For example, Malaysia, which is one of the claimants in the South China Sea, has a defense alliance in the Five Power Defense Arrangement (FPDA) together with Britain, Australia, New Zealand and Singapore. Meanwhile, the Philippines is bound by a defense pact with the United States.

The disruption to the north of the Natuna islands in the South China Sea conflict will also have an impact on Indonesia's economy directly from the results of exploration of oil and gas mining in the EEZ region (Keyuan, 2012). So far, the natural gas fields in the Indonesian EEZ region have made a very significant contribution to state revenue and have made Natuna Regency as one of the 
autonomous regions with the largest APBD in Indonesia. The ZEEI region in the South China Sea has contributed a lot to Indonesia's oil and gas revenues, which is around 30 percent.

The D-Alpha gas field, located $225 \mathrm{~km}$ north of Natuna Island, with a total reserves of 222 trillion cubic feet (TCT) and 46 TCT of hydrocarbon gas, is one of the largest sources in Asia(Siregar, n.d.). With the conflict in the South China Sea, the oil and gas production process in Natuna was disrupted and this resulted in a reduction in state income from oil and gas(Schofield, 2013). Furthermore, the sovereignty of the Republic of Indonesia will also be disrupted because of this conflict. Indonesia as an archipelago cannot ignore its interests in the South China Sea. This interest is related to the use of the Exclusive Economic Zone guaranteed by the United Nations for ratifiers of the Law of the Sea (UNCLOS) 1982. Outside the territorial territory, the coastal state does not have full sovereignty but has sovereign rights, namely the right to manage the sea for exploration purposes(Dodds \& Ingimundarson, 2012).

Based on these provisions, Indonesia has sovereign rights in Natuna waters and is actually entitled to explore natural resources there. However, China has even banned all Indonesian activities in the South China Sea. On the other hand, the Chinese government even carries out illegal activities on the ZEEI, by operating fishing boats that are escorted by the Chinese Coast Guard. The Natuna Islands are part of vital national interests and an integral part of the Republic of Indonesia, which actually cannot be contested by anyone. No country has the right to explore without a permit for Natuna Sea resources, including fish in Indonesia's EEZ as was done by Chinese fishermen. The Ministry of Maritime Affairs and Fisheries (KKP) reported that six ships from foreign countries namely three from Vietnam and three from the Philippines, caught by PSDKP officers in the North Sulawesi Sea carrying out illegal fishing activities in the Natuna waters bordering the South China Sea The confiscated Philippine ships caught 25 tuna, with a total weight of up to 250 kilograms. Meanwhile, Vietnamese boats were found stealing fish as much as $50-200 \mathrm{~kg}$ per boat. The South China Sea contains considerable fishery potential for Indonesia. Data from the Ministry of Marine Affairs and Fisheries (2001), shows that the fishery potential in the South China Sea is 1,057.05 tons, while the production that has been cultivated is only 379.90 tons or it is classified as an underfishing area. In Natuna itself, Minister of Marine Affairs and Fisheries Susi Pudjiastuti assessed that the fisheries sector is estimated to reach USD 400 million or around IDR 5.26 trillion (estimated exchange rate of IDR 13. 166 / USD). Illegal fishing practices that occur are very detrimental to local fishermen and threaten the sustainability of marine and fishery resource management in Indonesia. The breach caused enormous losses.

The South China Sea conflict will of course also have an impact on Indonesia's trade traffic with the countries that are cooperating with Indonesia. This will threaten the continuity of Indonesia's trade with the economic giants in East Asia, which based on statistics, these countries are one of Indonesia's important economic partners. This condition is certain to have a direct effect on Indonesia's domestic economy in the future.

In addition, the indirect economic effect is the increase in insurance costs for merchant ships carrying Indonesian export commodities to the East Asia region. Meanwhile, Indonesia's trade value through the South China Sea international trade route to countries in the East Asia region is quite high in the ASEAN-China Free Trade Zone (ACFTA) and the Japan-Indonesia Economic Partnership Agreement (JIEPA). The South China Sea is also Indonesia's export-import traffic towards East Asia, such as China, Taiwan, Japan and South Korea. If a war occurs in the sea area, it will disrupt the flow of Indonesian trade. In addition to reducing the interest in FDI (Foreign Direct Investment) to invest in the ASEAN region, the conflict also has the consequence of causing competition for military power,

Another major influence due to the South China Sea conflict is the emergence of modernization of military equipment from all ASEAN countries. Modernization of defense forces, especially maritime forces around the South China Sea, is an attempt by countries to secure their respective interests in these waters. The increase in conflicts that occurred in the region indirectly encouraged Southeast Asian countries to continue to modernize in the field of national defense. 


\subsection{Indonesia's Efforts in Resolving South China Sea Conflict}

The resolution of the South China Sea conflict is a difficult thing to achieve. It is difficult because there are more than five countries involved in the conflict. Disputing countries also have different attitudes in finding ways to resolve conflicts. Likewise, China only wants the South China Sea conflict to be resolved by bilateral negotiations with conflicting countries, while the Philippines and Vietnam want conflict resolution through multilateral forums in accordance with the provisions of applicable international law.

Until now, the claimant countries have not clarified each other regarding their claims. They haven't officially claimed the boundaries they want. Like China, which only made the nine dashed lines in general, without any clear coordinate points. It also adds complexity to resolving conflicts. The only urgent thing that is needed by the countries involved is how to keep regional conditions stable, while waiting for the common ground of the countries to resolve the conflict. Efforts to resolve the South China Sea conflict peacefully must always be endeavored because this concerns the interests of many countries.

As the largest country in ASEAN, Indonesia has a responsibility to maintain regional stability. In addition, even though it is not a claimant country, the impact of the South China Sea conflict regarding Indonesia's national interests will not be able to directly resolve conflicts between countries in the region, unless permitted by the country concerned. So what Indonesia can do is encourage these countries to resolve each other's conflicts peacefully.

The conflict resolution process is still very long and will likely take several years. The most important thing right now is how the situation in the region can remain stable with mutual trust between claimant countries. Indonesia has played a major role in making this happen. Through several mechanisms, Indonesia has attempted to direct the countries involved in the South China Sea conflict towards beneficial cooperation.

\subsection{Initiatives for Confidence Building Measures.}

The biggest factor in the emergence of state claims to the South China Sea is the natural resource potential contained in the region. Sovereignty over the islands in the region is also disputed because of their strategic location, very close to international shipping routes. It can be said that the South China Sea region has economic, political and strategic value. If managed properly, the South China Sea will actually be of great benefit to the surrounding countries. To achieve this, what can be done is to reduce conflict tensions such as establishing cooperation between the countries involved. Cooperation will protect the economic, political and security interests of each country and above all, create stability in the region. From an economic point of view, The countries involved will benefit from cooperation in exploration and exploitation for the development of their countries. From a political perspective, cooperation will create good relations between countries in the region. Meanwhile, from a defense perspective, cooperation will certainly keep the area safe and stable. On the basis of these principles, Indonesia took the initiative to spearhead a forum for claimant countries to discuss possible cooperation in the South China Sea. Canada supports this idea. Canadian support is provided as part of their program, namely Management for Changes, which was formed to manage world changes peacefully and develop cooperation. In this case, Indonesia has taken advantage of the Management for Changes program for the benefit of resolving the South China Sea conflict. To date, 26 workshops have been held with Indonesia as the host. It can be seen as shown in the following table. Since its inception, the workshop formulated and agreed on some basic principles for managing potential conflicts. The 2nd workshop in Bandung in July 1991 had recommended to the relevant government which then became an element for various declarations or code of conduct in the South China Sea. This workshop continues to be carried out consistently every year, with Indonesia as the host. After 20 years of regular meetings, there has been almost no more confrontation between the disputing countries. At the 2oth workshop, the then Minister of Foreign Affairs of the Republic of Indonesia, Marty Natalegawa, states that the facts show that since 1990 there has been no armed conflict in the South China Sea region. This is a testament to the success of the South China Sea workshop initiated by Indonesia 


\subsection{ASEAN-China Partnership Mechanism}

The regional approach by ASEAN is used by Indonesia as an effort to achieve conflict resolution. ASEAN itself was formed with the aim of enhancing regional peace and stability. Since its inception, ASEAN has upheld the principles of peace and stability, especially in Southeast Asia. In addition, to be able to face China, it is hoped that ASEAN countries will be more united so that they have a balanced decision and it will be easier to negotiate with China. Under the provisions of the Law of the Sea (UNCLOS 1982), states bordering closed or semi-closed seas should cooperate with each other in exercising their rights and obligations through appropriate regional organizations. As a regional organization that gathers and fights for the interests of countries in the Southeast Asian region, ASEAN is certainly trusted to play a role in pursuing a peaceful conflict resolution against the South China Sea which not only involves ASEAN member countries but also China. In response to the ongoing conflict tensions, ASEAN has issued the ASEAN Declaration on the South China Sea which was signed by ASEAN member countries in Manila on July 22, 1992. The principles contained in this declaration known as the Manila Declaration, among others, are: emphasizes the need for peaceful dispute resolution and encourages cooperation exploration related to safety of maritime navigation and communication, protection of the marine environment, search and rescue coordination, efforts to combat piracy at sea and armed robbery and illicit drug trafficking. After the Manila Declaration, the situation in the South China Sea is still heating up. In 1995, ASEAN took the initiative following the Mischief Reef incident to prevent existing disputes from escalating into conflict. The idea of a code of conduct was formally endorsed at the 29th ASEAN Ministerial Meeting (AMM) 1996 with the hope that it would provide a basis for long-term stability in the region and promote understanding between the countries concerned. Although the code of conduct has been considered as the main objective, after almost 5 years of negotiations ASEAN and China have only reached a political document.

\subsection{ASEAN Internal Mechanism}

As part of an ASEAN country, Indonesia needs to ensure that the countries within it have a unity and realize their position as a regional organization. China's military strength is still stronger when compared to the combined military forces of ASEAN countries. For this reason, in facing the power of China, of course ASEAN cannot run independently, but ASEAN must be more solid. To achieve this, Indonesia plays a role through ASEAN meetings. When a joint statement on the South China Sea conflict was not reached, Indonesia undertook diplomacy to change the situation. In 2012, the 45th ASEAN Foreign Ministerial Meeting in Phnom Penh, Cambodia failed to reach an agreement. Divisions between ASEAN countries occurred when Cambodia and the Philippines had different attitudes regarding whether or not to include the territorial dispute incident between China and the Philippines in Scarborough into a joint communique. The Philippines accuses Cambodia of being influenced by China. To respond to these differences of view, the Indonesian Minister of Foreign Affairs at that time, Marty Netalegawa, approached and shuttle diplomacy with the ASEAN Foreign Ministers regarding the Joint position.

For two days, from 18 to 19 July 2012, the Indonesian Foreign Minister acted as a mediator and visited ASEAN countries one by one. Indonesia underlined the importance of ASEAN acting with one voice and reminded that the latest developments are the concern of all ASEAN members. The consultation between the Indonesian Foreign Minister and the Foreign Ministers of the Philippines, Vietnam, Malaysia, Singapore and Cambodia for approximately 36 hours resulted in an agreement on ASEAN's Six Point Principles on the South China Sea on July 20, 2012. To prevent the incident in 2012 from happening again, Foreign Minister Retno Marsudi perform political maneuvers. Within three days, Retno Marsudi conducted marathon diplomacy. to meet separately with ASEAN Foreign Ministers to help build consensus. He also took the initiative to conduct an informal retreat before the start of the 49th official series of AMM. In this informal retreat, Retno Marsudi reminded that currently the international world view is being directed towards ASEAN on how ASEAN will respond to the PCA decision on the demands of the Philippines. On that occasion, Indonesia also suggested the ASEAN Point Ministers on Peace, Security and Stability in the Region statement. This statement essentially 
emphasizes that ASEAN in maintaining peace and stability in the region must protect their "home" so that it remains a peaceful and stable region. The statement also affirms ASEAN's commitment to maintaining and promoting regional peace, security and stability, as well as upholding the United Nations Charter, ASEAN Charter, and the Treaty of Amity and Cooperation in Southeast Asia in carrying out relations between countries.

Finally, the Foreign Ministers of ASEAN countries succeeded in reaching an agreement to arrange a joint communique at the 49th AMM in Vientianne, Laos, Tuesday, July 26 2016. The Joint Communique Agreement contains ASEAN's shared views on the development of the situation in the South China Sea. In this regard, ASEAN member countries affirm their commitment to fully respect the legal and diplomatic process. ASEAN countries are also committed to resolving territorial problems in accordance with the provisions of international law, including the Law of the Sea 9 UNCLOS 1982. Indonesia's role cannot be separated from achieving a common position with ASEAN. Thanks to the efforts made by Indonesia, ASEAN has agreed on a way to respond to the South China Sea conflict. As previously discussed, the Joint Working Group and Senior Official Meetings on DoC meetings were discussed to create a $\mathrm{CoC}$ framework between ASEAN and China and China. It is difficult to make this framework because each country has an interest in it. China did not want to accept the draft made by the Philippines while the Philippines did too. The most important thing is how to make these countries realize that this framework has to be created from scratch and that this $\mathrm{CoC}$ framework is something very important so that this can be achieved. Finally, in an informal ASEAN meeting in September 2012, Indonesia distributed the initial draft (zero draft) $\mathrm{CoC}$ on the South China Sea to ASEAN foreign ministers.

Indonesia took the initiative to offer the zero draft to be discussed together. The zero draft $\mathrm{CoC}$ was proposed at least as a trigger for the initial negotiations. The contents are fairly detailed and can be used to avoid "miscalculation" between all parties when meeting in the field. Indonesia has a draft, What is important for Indonesia is that the important elements according to Indonesia which from the draft are included in the $\mathrm{CoC}$ framework, so it does not matter if the zero draft made by Indonesia is accepted or not as long as the desired element is included in the $\mathrm{CoC}$ framework and that is what it is trying to do. How do we encourage the elements which Indonesia considers important to be included in it. So when negotiating the strategy must be changed. During the last three negotiations this year if I'm not mistaken, it was the beginning of the year in Bali, first in Bali, then in Cambodia, then in Buyang. So, in the end, we decided to use the Indonesian proposed approach again.

This is the role of Indonesia, what happens when there are dynamics between claimant countries, so that the process continues and can produce something. So we call it the Bali approach because this meeting started in Bali. In terms of efforts to implement $\mathrm{CoC}$, in July 2017 the CoC framework was submitted. The achievement of $\mathrm{CoC}$ has been eagerly awaited by many countries. Every country should realize that this $\mathrm{CoC}$ framework is very important so that it can be implemented immediately. Within this $\mathrm{CoC}$ framework, there are common elements in Indonesia's zero draft. Indonesia has been successful in encouraging or incorporating key points into the $\mathrm{CoC}$ framework. there are the same elements in Indonesia's zero draft. Indonesia has been successful in encouraging or incorporating key points into the $\mathrm{CoC}$ framework. there are the same elements in Indonesia's zero draft. Indonesia has been successful in encouraging or incorporating key points into the CoC framework.

\section{CONCLUSION}

Achieving South China Sea conflict resolution is not only beneficial economically, but also politically and securely for every country involved. The large economic potential such as shipping lanes, natural content of oil, gas and minerals as well as fish wealth if managed properly will actually be of great benefit to every country in the region. The impact of conflict resolution can not only be enjoyed by communities around the South China Sea but also for Indonesia and the international community. Indonesia cannot directly resolve conflicts because Indonesia is not a claimant country. What Indonesia can do is encourage countries that have claims in the South China Sea to talk to each other 
and resolve their problems peacefully. The conflict resolution process is still very long and will take many years. and the most important thing is how to manage the situation in the region so that it remains stable with trust among claimant countries. Despite the complexity of the conflict, Indonesia cannot ignore this. Indonesia cannot force countries to resolve their respective internal conflicts. However, as the largest country in ASEAN, Indonesia has a responsibility to maintain regional stability. Indonesia has played a major role in Indonesia's efforts to build Confidence Building Measures and hold dialogue between ASEAN countries and even China has been able to reduce sources of conflict that can arise from conflicts between claimant countries.

\section{REFERENCES}

Acharya, A. (2014). Constructing a security community in Southeast Asia: ASEAN and the problem of regional order. Routledge.

Beckman, R. (2013). The UN Convention on the Law of the Sea and the maritime disputes in the South China Sea. Am. J. Int'l L., 107, 142.

Chakraborti, T. (2012). China and Vietnam in the South China Sea Dispute: A Creeping 'Conflict-PeaceTrepidation'Syndrome. China Report, 48(3), 283-301.

Chaturvedy, R. R. (2015). South China Sea: India's maritime gateway to the Pacific. Strategic Analysis, 39(4), 360377.

Coker, C. (2015). The improbable war: China, the United States and the continuing logic of great power conflict. Oxford University Press.

De Castro, R. C. (2012). The risk of applying Realpolitik in resolving the South China Sea Dispute: implications on regional security. Pacific Focus, 27(2), 262-289.

Delisle, J. (2012). Troubled waters: China's claims and the South China Sea. Orbis, 56(4), 6o8-642.

Dodds, K., \& Ingimundarson, V. (2012). Territorial nationalism and Arctic geopolitics: Iceland as an Arctic coastal state. The Polar Journal, 2(1), 21-37.

Dutton, P. (2011). Three disputes and three objectives: China and the South China Sea. Naval War College Review, $64(4), 42-67$.

Gao, Z., \& Jia, B. B. (2013). The nine-dash line in the South China Sea: History, status, and implications. Am. J. Int'l L., $107,98$.

Hayton, B. (2014). The South China Sea: the struggle for power in Asia. Yale University Press.

Hong, N. (2012). UNCLOS and ocean dispute settlement: Law and politics in the South China Sea. Routledge.

Hu, N.-T. A., \& McDorman, T. L. (2013). Maritime Issues in the South China Sea: Troubled Waters or A Sea of Opportunity. Routledge.

Johnson, J. S. (2015). Qualitative sales research: An exposition of grounded theory. Journal of Personal Selling E Sales Management, 35(3), 262-273.

Kaplan, R. D. (2011). The South China Sea is the future of conflict. Foreign Policy, 188, 76.

Keyuan, Z. (2012). China's U-shaped line in the South China Sea revisited. Ocean Development E International Law, 43(1), 18-34.

Laksmana, E. A. (2011). Indonesia's rising regional and global profile: does size really matter? Contemporary Southeast Asia, 157-182.

Pedrozo, R. (2011). The Building Of China's Great Wall At Sea. Ocean \& Coastal LJ, 17, 253.

Pertiwi, S. B. (n.d.). Explaining China's Growing Assertiveness in the South China Sea Conflict from 2007-Present. Academia. Edu.

Pham, V. (2016). The Use or Threat of Force in the South China Sea Disputes Since 1945: A Timeline. In Power Politics in Asia's Contested Waters (pp. 523-539). Springer.

Rustandi, A. (2016). The South China Sea Dispute: Opportunities for ASEAN to enhance its policies in order to achieve resolution. Canberra: Center for Defence and Strategic Studies.

Schofield, C. (2013). What's at stake in the South China Sea? Geographical and geopolitical considerations. In Beyond Territorial Disputes in the South China Sea. Edward Elgar Publishing.

Scott, D. (2012). Conflict Irresolution in the South China Sea. Asian Survey, 52(6), 1019-1042.

Siregar, C. N. (n.d.). Peran Sosial, Ekonomi, dan Budaya Masyarakat dalam Meningkatkan Keamanan di Kabupaten Natuna Privinsi Kepulauan Riau. Jurnal Sosioteknologi, 9(21), 945-956.

Song, Y. (2015). South China Sea Arbitration Case Filed by the Philippines against China: Arguments concerning Low Tide Elevations, Rocks, and Islands. China Oceans L. Rev., 294.

Storey, I. (2013). Japan's maritime security interests in Southeast Asia and the South China Sea dispute. Political 
Science, 65(2), 135-156.

Sussangkarn, C. (2011). Chiang Mai Initiative Multilateralization: origin, development, and outlook. Asian Economic Policy Review, 6(2), 203-220.

Yahuda, M. (2013). China's new assertiveness in the South China Sea. Journal of Contemporary China, 22(81), 446459 . 